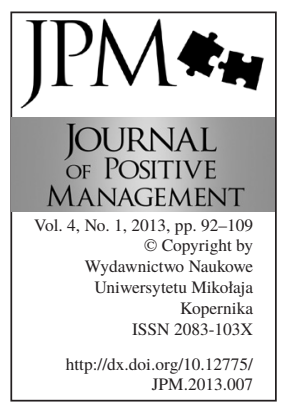

\title{
MARKETING SELF-DIAGNOSTIC TOOL FOR SMES - ASSUMPTIONS OF THE PROJECT ${ }^{*}$
}

\author{
Piotr Weryński \\ Department of Applied Social Sciences, \\ Faculty of Organisation and Management, \\ Silesian University of Technology, Gliwice, Poland, \\ e-mail: p.werynski@interia.pl
}

\begin{abstract}
Purpose: The aim of the author is to present methodological approaches used to study the socioeconomic sector of micro, small and medium-sized companies of plans for a experimental testing tool (Marketing self-diagnostic tool) constructed for the diagnosis and self-diagnosis of individual attitudes, knowledge, skills and needs in the field marketing of innovation and innovation in marketing MSME entrepreneurs.
\end{abstract}

Methodology: The study was carried out using a triangulation approach to the methods, sources, researchers, cognitive perspectives. They took place in the framework of the project POKL: "The matrix for innovative entrepreneurship", carried out by the Department of Applied Social Sciences, Silesian University of Technology.

Implications: The project concerns the issue of marketing innovation and innovation in marketing in 6 dimensions: competencies, perception of environment, customer orientation, awareness of the created brand, processes and strategies, pro-innovative trends and actions.

Originality / value: The project both in terms of methodology and substance is an innovative approach to the study of the socio-economic sector of micro, small and medium enterprises and the self-diagnosis in 6 dimensions: competence, perception of environment, customer orientation, awareness branding, processes and strategies, trends and pro-innovation activities.

Keywords: innovations in marketing, marketing needs, business relationship with the scientific community, branding awareness, marketing strategies

Paper type: Research paper

* The author presents the main assumptions made in the framework of the project POKL: "The matrix for innovative entrepreneurship" and the project: Marketing self-diagnostic tool for SMEs (MST), programme Marie Curie Industry-Academia Partnerships and Pathways (IAPP), Call: FP7-PEOPLE-2013-IAPP. 


\section{Introduction}

The problem of constructing the adequate and widely available instruments (procedures, methods and tools) for diagnosing the marketing needs in micro, small and medium-sized enterprises has been omitted until now, there are no instruments elaborated for them. The main idea and significance of the proposed project is the postulate to implement the widely available tool supporting the auto-diagnosis of the real needs from the field of innovation in marketing and marketing innovations for the current and future personnel in the sector of SME. In order to implement this idea in practice, it is necessary to find and elaborate such solutions so that it would provide the benefits in the form of collaboration between the sector of enterprises and universities. The introduction a multinational feature into project will allow to create a more objective, inter-cultural image of the real possibilities of collaboration and will indicate the real needs of both parties of the partnership.

\section{Scientific objective}

The combination of the target groups (universities and sector of SME) - in the aspect of the hereby project - is connected with the effect of complementarities and only thanks to the effect it will be possible to achieve the main objective of the proposed undertaking which is: the development and adjustment of qualifications and skills concerning innovation in marketing and marketing innovation for the scientific personnel of the chosen universities and the representatives of the chosen enterprises from the sector of SME in Poland and Slovakia.

The main objective will be realized in the way of completing the three basic detailed objectives:

- competences increase among the scientific and didactic personnel on teaching about the innovation in marketing and marketing innovation through the creation of the teaching programme and syllabuses and their popularization as the consequence of delegating, scientific exchange and knowledge transfer,

- adjusting the teaching programme of universities being the part of consortium for the needs of economy/market in terms of innovation in marketing and marketing innovation in the SME sector,

- knowledge and skills increase among the representatives of SME sector on marketing of innovative industrial goods and services through adjusting and next, implementing the auto-diagnostic tool on the Polish and Slovakian market (on the basis of diagnosing the project duration for the real needs of enterprises from SME sector).

Moreover, the objectives of scientific and technological character should be taken into account. The scientific objective comes to the educational-didactic level. It may be achieved thanks to the transfer of knowledge, experiences, solutions 
MARKETING SELF-DIAGNOSTIC TOOL FOR SMES

Piotr Weryński and skills among the consortium members: two universities of a different profile: technical university and humanistic university but they possess the faculties of management and four enterprises from the SME sector (in IT industry). At the same time it should be noticed that both universities and enterprises will be represented by two different countries from EU: Poland and Slovakia.

In turn, the technological objective will consist in the development and improvement of the electronic tool (online) for auto-diagnosing the real needs concerning the marketing of innovation and marketing innovation in the SME sector. The tool that is already possessed by the Silesian University of Technology (SUT) has been elaborated in frames of the project co-financed from the EU sources (European Social Fund, Operational Programme 'Human Resources Development') will constitute the basis for further research-scientific works (diagnosis and testing) in the international context. The tool was prepared by the scientific employees of the Department of Applied Social Sciences, Faculty of Organisation and Management at SUT and positively approved by the external Experts Council (scientists and practitioners representing other universities and institutions) as well as by employees of the Marshall Office of Silesian Region supervising the project.

The participation (job assignment) of the scientific employees of SUT in the project 'Marketing self-diagnostic tool for SMEs' assumes the transfer of knowledge and experiences towards the partners of consortium.

\section{Research methodology - key elements}

It is planned to undertake the diagnostic research in the field of marketing of innovation and marketing innovation (in the area of communication with environment, customers, brand building and inter-organizational competences, strategies and processes) as well as of the attitudes (Bohner and Wanke, 2004) to these issues represented by the personnel of SME and the diagnostic tools preferred by them (stage I). Furthermore, there will be the testing of the elaborated autodiagnostic tool realized as the diagnosis effect (stage II). The research problem consists in the border of social applied sciences and economy which translates into an interdisciplinary character of research. The research on the instruments for diagnosing the communication needs, interactions among the SME sector and market as well as social-cultural environment were based on the assumptions of a few paradigms (theories) from the field of management sciences [marketing and promotions mix conception (Kotler and Pfoertsch, 2008)], sociology of organizations [conception of methodological triangulation procedures (Weryński, 2012)], psychology [theory of needs transgression (Kozielecki, 2001)]. The research procedure is the realization of the methodological assumptions resulting from the aforementioned theories. 
The diagnosis of the needs of the enterprises from SME sector concerning innovation in marketing and marketing innovation requires a preliminary defining of two key notions: marketing innovation and innovation in marketing (Altkorn, 2004). The authors of the hereby application for the operational and analytical

MARKETING SELF-DIAGNOSTIC TOOL FOR SMES

Piotr Weryński needs assume that, similarly to research conceptualization, the marketing innovation are the non-standard solutions, not used previously in the activity of the enterprise, and being the consequence of the implementation of new sales policy. Innovations in marketing concern the significant, even revolutionary changes from the point of enterprise's view: change of product design, change of communication way of the enterprise with a customer, change of promotion channels and price strategy policy. These are the highly-targeted actions, personalized for the enterprise's environment as well as professional ones, which include the information technologies. These are also the actions directed on the examination of the satisfaction level of customers and contractors. The marketing innovation concerns both products and services of all the industries. However, the innovation in marketing is the analysis of marketing tools of innovation management and the scale of their use in order to introduce the new or considerably improved, innovative products and services. The innovation in marketing is also a constant search for new solutions as well as sales and communication channels.

The mainly inductive way of data collection and analysis will enable a constant verification and testing of research tools and scales constructed for the matrix. The methodological triangulation (Weryński, 2011) will also serve for it, which comes to, among others, adoption of quantitative and qualitative mutually verifying methods as well as experimental plan. The research process realized (the stage of diagnosis and the stage of tool testing) will constitute a cohesive entirety. The particular research actions will be linked by a strong cause and effect outcome.

\section{Research procedure}

1) Diagnosis of the state of knowledge, attitudes and opinions of the chosen academic and SME circles in the context of marketing needs and innovation attitudes.

1.1) Conceptualization and operationalization of the research problem (selection of theoretical and methodological base of the research the combination of detailed research questions) and the selection of sample's quantity for the quantitative research.

1.2) Construction of the questionnaire forms for the standardized interviews: for entrepreneurs, tools pilotage -20 forms.

1.3) Conducting 200 interviews with the entrepreneurs (for Polish and Slovakian party 100 each). 
MARKETING

SELF-DIAGNOSTIC

TOOL FOR SMES

Piotr Weryński
1.4) Construction of the databases in the SPSS programme for coding the data from interviews, construction of data matrix for defining the variables.

1.5) Results analysis of research on entrepreneurs and creating a partial report.

1.6) Effect of diagnosis stage - Marketing self-diagnostic tool for SMEs construction, tool preparation for the stage of testing.

1.7) Experts Council meeting evaluating the stage of diagnosis and partial reports.

2) Marketing self-diagnostic tool for SMEs testing

2.1) Experts Council meeting evaluating the draft version of the matrix (after the stage of diagnosis)

2.2) Constructing the Marketing self-diagnostic tool for SMEs testing - scenario and questionnaire form of observation for the focus group interviews, pre-test (ex ante) and post-test (ex post) for the participants of the focus group interviews, syllabus for the training classes with the experimental groups.

2.3) Tools pilotage - conducting the focus group interviews with the preand post-test as well as training workshops regarding the matrix in one (experimental) group, the second (control) group will not be under the stimulus influence, that is the training workshops.

2.4) Realization of the three focus group interviews with the pre- and post-tests on the experimental groups of recipients (students and $\mathrm{PhD}$ students and entrepreneurs) and of three training workshops as an independent variable in the experimental plan (see Figure 1).

2.5) Realization of the three focus group interviews with the preand post-tests on the control groups of recipients (students and $\mathrm{PhD}$ students and entrepreneurs) without the interaction of an independent variable.

2.6) Realization of the three focus group interviews with the pre- and post-tests on the experimental groups of users (scientific employees, coaches, entrepreneurs engaged in the project) and of three training workshops as an independent variable in the experimental plan.

2.7) Realization of the three focus group interviews with the pre- and post-tests on the control groups of users (scientific employees, coaches, entrepreneurs engaged in the project) without the interaction of an independent variable.

2.8) Realization of the three training workshops regarding the matrix with the pre- and post-tests without the focus group interviews with the experimental groups of users. 
2.9) Experts seminar conducted twice (specialists in the field of focus research and marketing) and discussion panels concerning the results obtained in the half-way and at the end of experimental plan.

2.10) Elaborating the research results of the Marketing self-diagnostic tool for SMEs testing in the experimental plan. Construction of the final product - The Matrix of Marketing Needs (MMN).

1. The experimental groups

\begin{tabular}{|c|l|c|c|}
\hline pre-test & focus & $\begin{array}{c}\text { workshop } \\
\text { (independent } \\
\text { variable) }\end{array}$ & post-test \\
\hline
\end{tabular}

2. The control groups

\begin{tabular}{|c|c|c|}
\hline pre-test & focus & post-test \\
\hline \multicolumn{3}{|c|}{ 3. The groups treated only independent variable } \\
\hline pre-test & workshop & post-test \\
\hline
\end{tabular}

The results obtained on the stage of diagnosis will enable the tool testing among the examined groups - the SME representatives. The tool will be subject to testing during the realization of experimental plan, that is the realization of focus group interviews with the pre- and post-tests, of workshops during which the participants get to know about the tool and interpretation of results. The comparison of knowledge state, using the post-test, among people from the control groups with the knowledge about the examined units from the groups under the influence of independent variable (training workshops using the materials constituting the substantial basis for the construction of the future matrix) will allow to indicate the difference in the knowledge level among the examined groups and at the same time, indicate the effectiveness of experimental actions. After elaborating the results there will be the experts seminar organized concerning the obtained results of the quantitative and qualitative research, the effect of which will be the final tool construction.

\section{Results of the experimental plan}

What conclusions may be drawn from matrix testing and internal evaluations on the basis of pre and post-tests in the project POKL?

In frames of the procedure testing there were pre and post-tests applied thanks to which the influence effects of independent variable on the interviewees from the experimental groups were measured. The test included 6 closed-ended questions, including one multiple choice question. When constructing the pre and post-test there was a rule adopted that each out of six dimensions of the MMN 
MARKETING SELF-DIAGNOSTIC TOOL FOR SMES

Piotr Weryński model tested, that is environment perception, customer orientation, awareness of brand creation, processes, strategies and competencies, is represented by one question in the test. The aforementioned independent (intervening) variable were the workshops where knowledge, skills and competencies directly corresponding to a topic range of matrix were transferred. Below there are the results presented obtained after a data compilation in SPSS program - from pre and post-tests as well as influence effects of independent variable (see more at: www.innowacyjnamatryca.pl).

Having compared the participants of workshops with the ones who did not take part in them, the first ones much more often provided the correct answers in the post-tests. When they were answering the question: In Your opinion, what should the role of enterprise's employees be in the process of implementing innovations?, they more often chose the correct answer: the key role, they should be initiators of implemented changes.

If we analyze the distribution of answers to the aforementioned question according to differences between the pre and post-tests, there may be an increase clearly noticed in knowledge of the interviewees who were providing answers on the stage of post-tests. The highest increase of correct answers may be seen between the pre and post-test if we concentrate on the selection differences of respondents concerning the first item of cafeteria of answers (key role of employees in the process of implementing innovation) in relation with all the remaining items from cafeteria. In other words, using the example above, it may be observed that the process of MMN tool testing (mainly: workshops organized but also focus group interviews conducted among the selected matrix users and recipients) triggered the expected changes of attitudes elements, knowledge increase, improvement of opinions and emotional attitude towards the matrix and its applications.

The interviewees of the experimental groups who participated in the workshops, comparing to the people who did not take part in the workshops, much more often provided the correct answer to the question: What should an innovative enterprise mainly focus on? The proper answer, that is possibilities and opportunities provided by the environment was chosen much more often than problems and threats embedded in the environment in both pre and post-tests although in the post-test the first answer was selected over twice more often than in the pre-test.

When analyzing the next questions there may be a rise noticed concerning the positive answers in the post-tests in the cases when the interviewees took part in the workshops. The participants of the stage of MMN testing were asked the question: What is the superior objective of innovative brand? In the posttests the highest increase in answers was obtained in selecting the only correct item: building trust and customer loyalty. In terms of the two remaining answersrecognition (recognizing the category of product) and high quality of enterprise's 
communication with environment - the number of indications doubled in the posttest but it was considerably lower than the leading answer.

The selections of answers to the question about competencies in the posttests may be interpreted in a similar way: How does an innovative entrepreneur understand the notion of change? The answers possible were: as an opportunity for something positive, as something harmful and unnecessary and as a great uncertainty.

After conducting the workshops the number of correct answers to the aforementioned question increased over twice which is as an opportunity for something positive.

If we analyze the distribution of answers of MMN testing provided by the participants measured by the pre and post-tests, in case of the two next questions there is also increase of positive answers visible in the post-test even without the inclusion of independent variable (workshops). The questions were to indicate a superior objective of innovative brand and how an innovative entrepreneur understands the notion of change. However, the increase scale is not as clear as in the case of examination made after conducting the workshops among the investigated experimental groups when providing answers to the same questions. The control groups, that were not subject to the stimuli in the form of workshops, changed their attitudes towards the matrix and problem of innovation in MSME as they participated in the group discussions during the focus interviews. Nevertheless, in none of the groups there were comparable knowledge and positive attitudes noted towards the results obtained in the experimental groups, in which the workshops also took place.

The examined participants of Matrix of Marketing Needs testing in frames of taking the pre and post-test were also asked to answer one multiple choice question: Which aspects of innovative enterprise's functioning are of key significance in Your opinion? The answers to the question above were going to be a knowledge indicator in terms of the modules: processes and strategies. The test creators assumed that the more aspects of innovative enterprise's functioning are selected by the respondents, the greater range of knowledge they obtained concerning the aforementioned modules. After comparing the distributions of answers from the pre and post-tests it may be noted in the post-tests that, apart from one aspect: product/service price - the increase of selection of positive answers occurred in all the aforementioned dimensions of innovative enterprise's functioning. It also turned out that the tendency above was even clearer in the experimental groups. The people who took part in the workshops almost twice more often selected a full set of positive answers in the post-tests - in the view of interviewees who were not influenced by this variable.

The presented analysis on the distribution of answers of the examined participants of the experimental plan, that were obtained during the pre and post-
MARKETING SELF-DIAGNOSTIC TOOL FOR SMES

Piotr Weryński 
MARKETING SELF-DIAGNOSTIC TOOL FOR SMES

Piotr Weryński tests conducted, allows to state that among the interviewees, after completing the testing procedure, there was a knowledge increase noted concerning the innovation in marketing and marketing innovation as well as positive change of attitudes (interest and declaration of matrix use). The knowledge increase and change of attitudes' elements were observed when examining the answers regarding all the six post-test questions in relation with the answers obtained in the pre-test. Especially great knowledge, skills and competencies increase could be noticed in case of the experimental groups that were influenced by the independent variable. From the point of view of initial assumptions realization regarding the plan of final product testing (MMN) there were also noted, at a similarly high level, positive changes in the distribution of answers between the pre and post-tests in the particular groups of users and recipients.

The results obtained prove the correctness of the procedures and measures applied for tool testing (experimental plan). They are also a direct proof of adequacy of MMN constructed, adopted conceptual and methodological assumptions in relation to the users and recipients' needs identified on the stage of diagnosis. They also prove MMN effectiveness in reducing problems of the target groups. The application of Matrix of Marketing Needs is useful while knowledge, skills and competencies diagnosing among the target groups, it also allows the users, as a final effect, to create an independent Individual Development Path (Weryński, 2013).

\section{Target groups}

The social-economic problems and needs presented above are linked to each other, indicating the need for adjusting the skills obtained by the students to the needs of labour market. Taking into account the fact that the significance of the market of innovative products and services is becoming more important, the priority should become the skills enabling the existence/functioning of the students in this area, both as workers and owners of their own enterprises.

\section{Product users}

a) Target group of users are the technical, economic universities and faculties of management at other universities, lecturers who will use the matrix for diagnosing the marketing needs, being the outcome of the project, for conducting the classes and workshops with students and $\mathrm{PhD}$ students. The users of the same matrix as the Marketing self-diagnostic tool for SMEs will also be SME and their owners, including the university graduates who decided to launch their own economic activity;

b) Popularization and inclusions in frames of the project: the main group will consist of Polish and Slovakian technical and economic universities represented mostly by two groups: lecturers who have the 
potential possibilities of using the tool during their classes (conferences, workshops, seminars) and the university authorities who are able to include the elaborated programme (or its part) into the teaching programme (conferences, panel discussions). Total: at least 50 people. In

MARKETING SELF-DIAGNOSTIC TOOL FOR SMES

Piotr Weryński this stage there also be included: the students and $\mathrm{PhD}$ students, graduates from SUT and KU, who will receive the marketing self-diagnostic tool for SMEs as well as the computer programme and training materials. That is 200 more people. Firstly, we want to increase their awareness related to possessing the knowledge about the marketing of innovative goods and services, secondly, to encourage them to extend the knowledge on their own on the basis of products created in the project. Among the entrepreneurs of MSME sector there will be the tool popularization using the universities included in the consortium in the way of trainings (100 people), advising/consultancy (100 people) and conferences (150 people).

\section{Product recipients}

Target group of recipients will be the students, $\mathrm{PhD}$ students and graduates of two universities who will obtain the knowledge about the marketing of innovative goods and services as well as employees of SME who, after obtaining new marketing skills concerning the marketing of innovative goods and services, will be able to adjust them in their enterprises increasing their competitiveness on the market.

\section{Conditions which have to be fulfilled so that the innovation works properly}

The main condition which has to be fulfilled so that the innovation works properly (beside the methodology of scientific research in compliance with the requirements: conducting the stage of diagnosis on the situation of SME and reliable tool testing) is the preparation of the key group - users. The users of the final product will be prepared in an especially reliable way (in a quasiexperimental test plan with workshops) to the future matrix adoption, both in the didactic processes at SUT and KU as well as in the economic practice - in the enterprises included in the research from the stage of diagnosis, through the stage of matrix testing, finishing at the popularization during conference, workshops, in the advising/consultancy point, on-line consultations and during the use of interactive version of the matrix on the website of the project. The application of the monitoring and evaluation procedure created by the project team allows to eliminate the errors on a regular basis and to correct the actions is such a way that the undertaking will be fully successful.

The product users will take part in the aspect of tool testing and evaluation lecturers of SUT and KU (30 people from each university). There will be mainly 
MARKETING SELF-DIAGNOSTIC TOOL FOR SMES

Piotr Weryński the quantitative methods of evaluation used, included in the quasi-experimental plan: focus group interviews and workshops, which will be preceded and finished with survey (pre, post-test) on the knowledge and opinion about the matrix. The stage of tool testing and evaluation also will be participated by the entrepreneurs from micro, small and medium-sized Polish and Slovakian enterprises who introduce innovative product and technologies (20 people for each university, including 10 women and 10 men) who will be engaged (as consultants) into the process of tool construction and testing (methods of testing and evaluation the same as above). They will provide the valuable remarks concerning the differences between the theory and practice in implementation (including promotion) of innovative services and products. Their practical knowledge is essential in creating the tool which may be used effectively by Polish and Slovakian SME.

In the aspect of tool testing and evaluation as the product recipients - the BSc (BA) students of full-time and extramural studies on the second and third year, $\mathrm{PhD}$ students at SUT and KU and entrepreneurs from SME who will be reached by the project creators through the databases of SUT (total 150 people, including 90 students, $30 \mathrm{PhD}$ students, 30 employees of SME).

\section{The current state of knowledge}

The Applicants conducted research on the current state of knowledge in the area that is the subject of this project. The basic sources of the research were, among others: scientific papers, professional internet industrial portals, reports from scientific research and published books.

Two on-line diagnostic tools were identified that are similar to the instrument presented as the subject of this project. Both tools as essential and formaltechnical solutions were created in the countries of the European Union in the period analogical to the one of the Polish tool, which is in years 2010-2011. The first of them functions as a result of work of Austrian researchers [1], the second one operates as a German construction [2].

The scientific approach to the problem of market research encourages the conducting of critical analysis of the identified tools in the context of the instrument that is the subject of this application.

The main similarities appearing in all three tools are:

1) Holistic reference to the marketing processes and innovations in the commercial sector of the market economy based on precise diagnostics (conceptualization and operationalization of research questions, quantitative analyses of results achieved),

2) The tools were created on the basis of psychometric methodology,

3) The result of using the tools is a generated diagnostic report,

4) The tools are user-friendly and intuitive.

The main differences include: 
1) The Polish tool was created on the basis of specific, young free-market economy. The tools from Western Europe are based on the results of research in the area of long-term traditions of established capitalistic economy;

2) The tools created in Poland are addressed specifically to the sector of micro, small and medium-sized enterprises, the Austrian tool is used to analyze creativity and innovativeness of employees and their organizations, it is a support tool for establishing partner relationships in the sector of services in the area of licensing agreements and large firms for further projects. The German tool on the other hand is addressed to the medium-sized and large companies, examines mainly the creativity (and not innovations) in the industry (not in the services);

3) The Polish product was created thanks to funding from the means of European Social Fund, Operational Programme 'Human Resources Development', because of which it automatically became an open, free and available application;

4) The German product is focused on innovation, Austrian product on creativity and the innovative potential of organizations and employees. The Polish product is focused only on issues of marketing innovation as well as innovation in marketing in the area of industrial goods and services, it is the result of scientific (engaging scientific employees from the SUT) and business perspectives (diagnosis of the condition and active participation in the project of enterprises from the sector of micro, small and medium-sized enterprises).

The holistic part of the tool is considered in the context of six dimensions of innovation as presented in Figure 2.

All in all, it should be noticed that the construction of the specialized tool for diagnosing attitudes (knowledge, skills and behaviours) in the area of marketing innovation and innovation in marketing solely for the sector of small and mediumsized enterprises in the form of an auto-diagnostic tool working using an on-line formula has never been published before. Therefore, the idea has to be considered as innovative and unique. It is the expansion of a local (regional, provincial) project 'With the matrix to the innovative entrepreneurship', where we deal with the same originators. The basic, introductory object for regional research was the diagnostics of the condition of enterprises in the sector of small and mediumsized enterprises in the area of the Silesian province (representative sample of 300 companies), the result of which clearly pointed out significant shortcomings of the entrepreneurs and employees of the companies in the area mentioned. In the present times of absolute competition, producing goods or offering services of high quality is not a problem; the problem is to skilfully introduce the product to the market and to sell it successfully. According to the results of the 
Piotr Weryński

Figure 2.

Six dimensions of innovation

Source:

Weryński (2012).

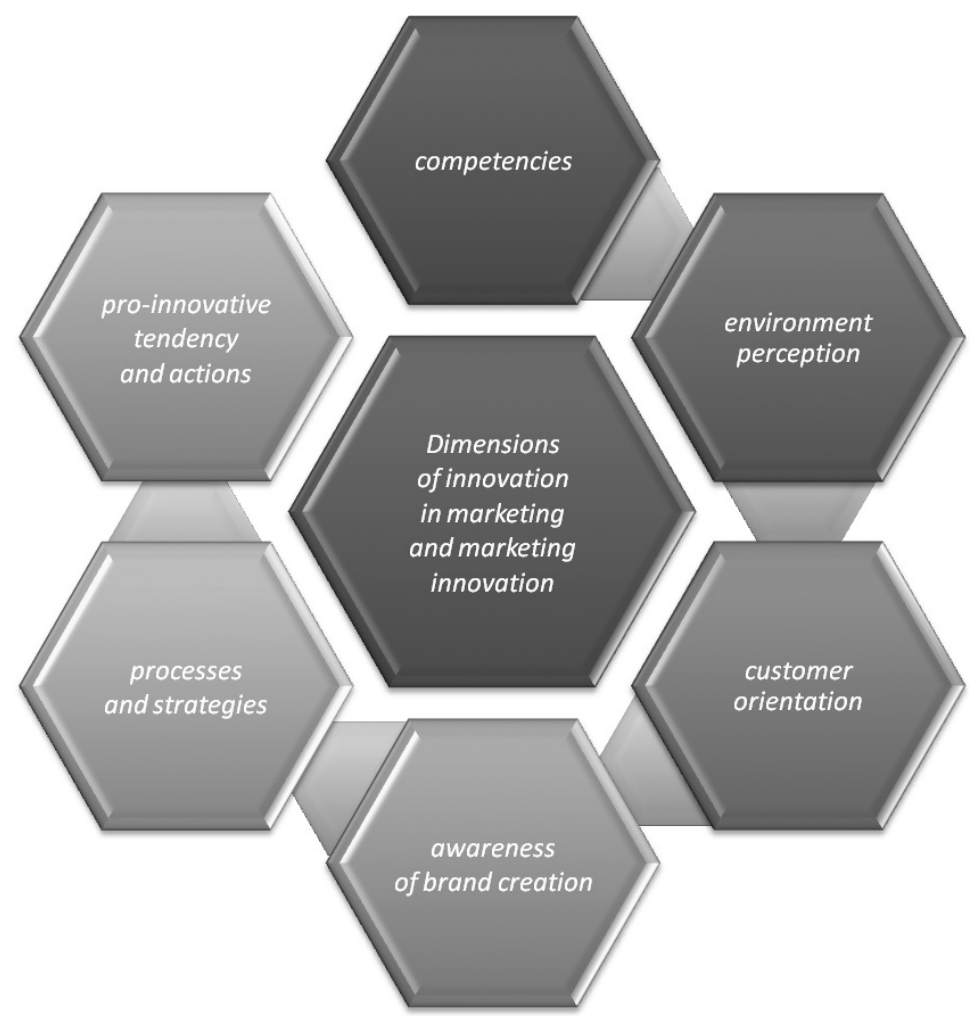

diagnostics, the most significant problem of small and medium-sized enterprises, both manufacturing as well as service oriented is the ability to use an innovative approach to distribution, packaging, advertising and promotion and finally, to successful sale of the product or service. The auto-diagnostic tool makes it possible not only to obtain the opinion and the diagnosis of the current condition, but in its expansion it will show all of the possible aspects of increasing or gaining knowledge in the area of marketing innovation and innovation in marketing. The current level of knowledge in this field is enormous and is still developing, however, according to the understanding of the Applicants no successful tool analogical to the subject of this project has been created before.

\section{The effects of the innovation}

The project concerns a problem that is poorly recognized, and therefore, there are no available standardized instruments used for solving it. The project of marketing matrix allows the use of already existing resources of SUT and KU (experienced researchers in the area of sociology, management, social psychology, marketing and PR, teams of interviewers and data analysts who are already prepared); 
infrastructure resources (computer programmes for analyzing quantitative and qualitative data) will make it possible to reduce the costs of the project to the highest extent, as well as to achieve the effect of synergy of resources provided by the universities, with a high guarantee of professionalization and credibility of the

MARKETING SELF-DIAGNOSTIC TOOL FOR SMES

Piotr Weryński research team. It will be expressed by, among other, using a number of types of scales in the construction of the matrix (tested appropriately, e.g. by the Cronbach alpha measure) to measure the distribution of certain examined variables, there will be the triangulation of methods, data and observers used which will increase the reliability of the tool.

The actions conducted for innovative SME up to this moment were of an accidental character (e.g. hiring an external consulting firm, marketing audits) as well as incidental (most often one-time). Up to this moment there was a lack of a tool allowing the enterprises to conduct the diagnoses of their needs on their own in the area of marketing of innovative goods and services as well as the correct choice of tools. Even if the enterprises felt the lack of such diagnostics tools there was a lack of a system tool that would allow them to take rational market actions. Because of the fact that the problem is not very well recognized, the design of the system tools requires bearing significant costs for conducting the thorough diagnostics and testing. These however, are one-time costs necessary for designing the tool, the use of which will not require the users to bear any additional costs. In case of the popularization of the matrix of marketing needs among the target groups there is a chance for decreasing the costs of diagnoses and marketing audits for medium-sized companies, while for many micro and small enterprises that cannot afford such actions, a cheap method that is also easy to use on one's own for diagnosing marketing needs will be made available. Stopping the actions aimed at creating a tool for diagnosing the marketing needs of SME, with the particular emphasis on the needs of micro and small enterprises, indicated in the stage of diagnosis, will result in the lack of simple and cheap simulators for pro-innovative actions, such as the presented matrix and as a consequence it will result in further strengthening of the defensive marketing behaviours and a low level of innovation in the regional SME.

\section{The current tool construction}

The MMN consists of 6 scales (modules) in the current version, described by 21 closed-ended questions (number of items in the particular scales is not the same). Some part of questions is divided into items. The questions relate to different situations and facts describing the enterprises' functioning and they were formulated in such way so that they enable an adequate description for all: micro, small and medium enterprises. The situations and fact were selected on the basis of analysis of theoretical premises. The items constituting the scales were included into the questionnaire form in a random order. 
MARKETING SELF-DIAGNOSTIC TOOL FOR SMES

Piotr Weryński

Table 1.

Collective results

106
On the project website (www.innowacyjna-matryca.pl) and in the project publication (Weryński, 2012) there is a presentation of items in the particular modules and the answer key in a form of tables thanks to which it is possible to ascribe the types of answers to the type of enterprise.

A target form of the tool is auto-diagnosis using the server. The interviewees read the instruction themselves. The instruction defines the standardized conditions of research. The time for providing answers is unlimited. It is estimated that an average time of providing answers is 30 minutes. The respondents describe their own enterprise themselves indicating in what degree each of the mentioned activities describes the enterprise's functioning. Each question requires opinion in a form of selecting a particular option. Some questions use a 5-grade Likert scale that consists of cafeteria of 5 answers. The remaining questions are multiple choice ones. The results are calculated for each item separately, what enables generating a very precise description of the enterprise. The results are estimated individually for each scale using a special computer program or a traditional method, using answer key.

After providing answers for all the questions there is both, a general interpretation formed that consists in qualifying the interviewee to one of the groups: LI, In, PI as well as a detailed, qualitative interpretation that determines strengths and needs in six scales consistent with the elaborated modules. Such information is presented in Table 1 which is the table of collective results.

\begin{tabular}{|c|c|c|}
\hline MODULES & STRENGTHS & NEEDS \\
\hline COMPETENCIES & & \\
\hline ENVIRONMENT PERCEPTION & & \\
\hline CUSTOMER ORIENTATION & & \\
\hline AWARENESS OF BRAND CREATION & & \\
\hline PROCESSES AND STRATEGIES & & \\
\hline PRO-INNOVATIVE TENDENCY AND ACTIONS & & \\
\hline
\end{tabular}

\section{The final product}

The final product will be a matrix for diagnosing the marketing needs, i.e. a tool, methodology, programme and materials for teaching students and PhD students of the universities in the region as well as the entrepreneurs from SME sector in the area of marketing of innovative industrial goods and services. It will be made available in the form of a published book with a CD (available for those interested during the propagating conference, in the consulting point and in the propagating workshops), on the internet site there will be an interactive version of the matrix, on which those interested will be able to get information concerning the matrix, 
solve the test by themselves (auto-diagnosis) and download the tool in the form of a digital record (pdf file).

A value added also consists in a new substantial character of collaboration, started thanks to the project by scientific and business circles with a special role of 4 companies - members of a consortium, who will be working on the software for the auto-diagnostic tool and internet project applications (SME), furthermore, gathering knowledge about the SME environment, starting the collaboration with business circles on the stage of deepening the diagnosis, testing and popularizing the product.

The Matrix of Marketing Needs is supposed to enable an individual estimation of the position of the enterprise in the dimension of innovation. This objective will be achieved by positioning the enterprise in one of the three groups:

- Innovation Leader (IL; such organization is characterized by a very high level of knowledge in the area of innovation as well as by effectiveness of the innovative actions taken),

- Innovator (In, such organization is characterized by an average level of knowledge and skills in implementing innovative actions as well as by the readiness for acting and implementing resources),

- Potential Innovator (PI, such organization shows the large needs in the area of knowledge, awareness and possibilities of implementing innovative actions, a large amount of changes is advised).

The diagnostics procedure predicts individual testing, with a time of each test being around 25 to 30 minutes. The matrix is supposed to serve as a tool of auto-diagnostics of the entrepreneurs of the SME sector. In short time it will be providing significant information regarding the functioning of the enterprise related to the criterion of innovation. The tool will consist of between 20 to 25 closed questions with a detailed manual of answers provided. Each question of the matrix will constitute a formalized indicator of a particular variable that is estimated to be significant in the process of statistical analysis. Each of the questions will have a form including specific options of answers as well as rules of transforming the answers into a numerical result and a qualitative interpretation. After providing the answer for all of the questions it will be possible to form a general interpretation, based on the examined enterprise qualified to one of the three groups: LI, In, PI and a detailed qualitative one based on determining the strengths and needs in six dimensions consistent with the designed modules (competencies, environment perception, customer orientation, brand awareness, processes and strategies, pro-innovative trends and actions). 
MARKETING SELF-DIAGNOSTIC TOOL FOR SMES

Piotr Weryński

\section{Notes}

[1] The first may be accessed at the following address: http://www.enterprise-europe-network.ch/ marketplace/index.php?file $=$ bbs-show.php\&bbsref $=11 \% 20$ AT\%200102\%203L7Q.

[2] The second may be found using the following link: http://www.innovationcoach.com/solutions/ online-in-depth-audit/.

\section{References}

Altkorn, J. (Ed.) (2004), Podstawy marketingu, Wydawnictwo Instytut Marketingu, Kraków.

Bohner, G., Wanke, M. (2004), Postawy i zmiany postaw, Gdańskie Wydawnictwo Psychologiczne, Gdańsk.

Cole, G.A. (1995), Organisational Behaviour, DP, London.

Davis, A. (2007), Public Relations, Polskie Wydawnictwo Ekonomiczne. Warszawa.

de Chernatony, L. (2003), Marka. Wizja i tworzenie marki, Gdańskie Wydawnictwo Psychologiczne, Gdańsk.

Falkowski, A., Tyszka, T. (2006), Psychologia zachowań konsumenckich, GWP, Gdańsk.

Gilbert, J.T. (1994), "Choosing an Innovation Strategy: Theory and Practice”, Business Horizons, Vol. 37, No. 6, pp. 16-22. DOI: 10.1016/S0007-6813(05)80240-X

Harmon, P. (2010), "What is a Business Process", Business Process Trends, Vol. 8 No. 21, December.

Hill, N., Alexander, J. (2003), Pomiar satysfakcji i lojalności klientów. Oficyna Ekonomiczna Grupa Wolters Kluwer, Kraków.

http://www.bptrends.com/publicationfiles/advisor20101214.pdf (accessed August 2011).

Janasz, W., Kozioł, K. (2007), Determinanty działalności innowacyjnej przedsiębiorstw, PWE, Warszawa.

Kotler, Ph. (1999), Marketing. Analiza, planowanie, wdrażanie i kontrola, Felberg SJA, Warszawa.

Kotler, Ph., Pfoertsch, W. (2008), Zarzqdzanie marka w segmencie B2B, PWN, Warszawa.

Kozielecki, J. (2001), Psychotransgresjonizm. Nowy kierunek psychologii, Wydawnictwo Akademickie Żak, Warszawa.

Lambin, J.J. (2001), Zarzadzanie marketingowe, PWN, Warszawa.

Matusiewicz, M. (2005), „Public Relations: Teoria i wykorzystanie sieci”, Gazeta IT, 9 (39), Warszawa.

OECD, (2008), Eurostat, Podręcznik Oslo. Zasady gromadzenia i interpretacji danych dotyczacych innowacji, Ministerstwo Nauki i Szkolnictwa Wyższego, Departament Strategii i Rozwoju Nauki, wydanie polskie, Warszawa.

Ortt, J.R., van der Duin, P.A. (2008), "The evolution of innovation management towards contextual innovation", European Journal of Innovation Management, Vol. 11 No. 4, pp. 522-538. DOI:10.1108/14601060810911147

Patten, D. (2003), Skuteczny marketing w matej firmie, Helion, Gliwice.

Pomykalski, A. (2001), Zarządzanie innowacjami, Difin, Warszawa.

Rogers, E.M. (2003), Communication of innovations: a cross-culural approach, Free Pres, New York-London.

Solomon, M.R. (2006), Zachowania i zwyczaje konsumentów, Helion, Gliwice. 
Wach, K. (2008), Regionalne otoczenie małych i średnich przedsiębiorstw, Wydawnictwo UEK, Kraków.

Waniowski, P., Sobotkiewicz, D., Daszkiewicz, M. (2010), Marketing. Teoria i przykłady, Wydawnictwo PLACET, Warszawa.

Weryński, P. (2011), „Procedura triangulacyjna w badaniach aktywności obywatelskiej”, in: „Animacja Życia Publicznego. Analizy i Rekomendacje”, Zeszyty Centrum Badań Społeczności i Polityk Lokalnych, No. 2 (5), Warszawa, pp. 20-24.

Weryński, P. (Ed.) (2012), Matryca Potrzeb Marketingowych w sektorze MMŚP, Difin, Warszawa.

Weryński, P. (Ed.) (2013), Matryca Potrzeb Marketingowych w sektorze MMŚP. Testowanie $i$ upowszechnianie narzędzia, Difin, Warszawa.

Wójcik, K. (2001), Public Relations od A do Z, tom 1, Agencja Wydawnictwo Placet, Warszawa.

Zaltman, G., Zaltman, L. (2010), Metafora w marketingu, Dom Wydawniczy Rebis, Poznań. 
